\title{
Economic Analysis of Production of Essential Oil using Steam Distillation Technology
}

\author{
*K. Mu'azu, E.M. Okonkwo and M. Abdullahi \\ National Research Institute for Chemical Technology, P.M.B. 1052, Zaria, Nigeria \\ [*Corresponding author: e-mail: kabirumuazu@yahoo.co.uk. Tel: +234(0)8027106787]
}

\begin{abstract}
This paper examines the economical analysis of producing essential oil from leafy part of Eucalyptus citriodora plant using steam distillation technology. The specific objectives were to examine the viability or otherwise of this method of producing essential oil in terms of net profit generated, return on investment and pay back period. The data used in this study were obtained from series of test-run carried out on the fabricated essential oil pilot plant and other input costs were based on the current market price available in Zaria Area Council, Kaduna State. The results showed that the total estimated cost of the pilot plant (direct fixed cost) with capacity to produce 0.864 litres/hour of crude essential oil was $\$ 1,453,493: 00$ and annual operating cost (AOC) of 4,026,492:00. The plant is expected to produce 840 litres of distilled essential oil per annum with expected annual selling price of $\$ 6,300,000: 00$ and profit after tax (PAT) of $\$ 1,818,806.00$ at $20 \%$ tax rate. The return on investment (ROI) was $125 \%$, internal rate of return (IRR) of $29.64 \%$ and pay back period (PBP) of 0.75 years. From the profitability analysis and measure of return on investment carried out based on the various assumptions and projections made, it was quite obvious that the production of essential oil using steam distillation technology is highly profitable which should be attractive to potential investors.
\end{abstract}

Keywords: Essential oil, Eucalyptus citriodora, Steam, Distillation, Economical analysis.

\section{INTRODUCTION}

Essential oils are the odoriferous constituents of plants. They occur in various sites of the plant anatomy and in some cases are found throughout the plant organs and in other cases are restricted to specific sites. These parts of plant organs include flower, fruits, leaves, roots, seeds and bark (UNIDO, 1983). The oils are form in the green (chlorophyll bearing) parts of the plant tissues, particularly in the flowering shoots. The exact function of essential oils in a plant is unknown, it may be to attract insect for pollination, or to repel harmful insects or it may be simply a metabolic intermediate (Encarta, 2003).

The oils are mainly used in perfume industry with some used in food industry in the manufacture of drugs, soaps, toiletries, cosmetics, paints, food, etc. (www.kevala, 2003). Apart from those uses mentioned above, studies have also shown that some essential oils have antimicrobial and antifungal effects on some phartogenic organisms which make it to be useful in pharmaceutical industry (Daw et al., 1995, and Sridha, 2003)

The yield of essential oils is naturally constrained ranging from $0.5-6 \%$ by weight (exception being clove buds, 11-15\%) (UNIDO,1983). Though, essential oils have relatively high sales value of approximately $\$ 13,000 / \mathrm{kg}$ (Grarry et al., 1995). This means that even relatively low quantities of these oils have a high sales value.

In 1993, the world sales value of fragrances and flavours was $\$ 19$ billion US dollars (Galadima, 2004). Out of this amount Nigeria did not earn anything but rather spent about \$14 million US dollars on importation of flavours, fragrances and 
essential oils between June and December, 1994 (Igwe, 2000).

Different methods are employed for the extraction of essential oil from plants material. These includes steam distillation, water distillation, water-steam distillation, expression, solvent extraction, maceration, super critical fluid extraction and sub critical fluid extraction (Kirk- Otherma, 1995 and Mustapha et al., 2003; Galadima, 2004). The most common method is steam distillation. This involves generating steam in a boiler and passes across packed bed of leaves arranged in tank still. The steam produced travels upward and extracts the oil from the leave and finally gets into condenser for condensation. The water-oil mixture forms two layers in the oil separator and gets separated. The crude essential oil is further redistilled to get pure essential oil (Okonkwo et al., 2006).

Despite the availability of basic raw material in Nigeria, the production of essential oils is negligible. The low yield of the essential oils, over dependency on petrodollar and lack of encouragement by various tiers of Government (most especially state and local Governments) towards production rather than importation are some of the important factors discouraging potential investors and entrepreneurs in the essential oil industry.

National Research Institute for Chemical Technology (NARICT), Zaria, a parastatal in the Federal Ministry of Science and Technology has successfully designed, fabricated and test-run a pilot plant for steam distillation of essential oils from leafy part of plant material and presented to public at Raw Material Research and Development Council (RMRDC), Abuja. The plant used in the design was Eucalyptus citriodora leave with a yield ranging from 0.5-4.8\% (UNIDO, 1983). The pilot plant has a maximum production capacity of 0.864litres/hr per batch of crude essential oil and plant efficiency of about $85 \%$ (Okonkwo et al, 2006).

\section{Technology of Steam Distillation}

Steam distillation is the process of passing steam through a closely packed bed of plant material placed in a tank still. The steam may be obtained from external boiler or produced within the tank by boiling water using kerosene stove as source of energy. Emerging vapour from the packed bed of plant of material containing the volatile essential oil is led to condenser for condensation. The condensed water is then separated from the immiscible oil in a vessel called separator. Crude essential oil obtained from the separator may be further redistill, dried, filtered or centrifuged to improve its appearance and keeping quality. Figure 1 presents schematic diagram of essential oil pilot plant using steam distillation technology.

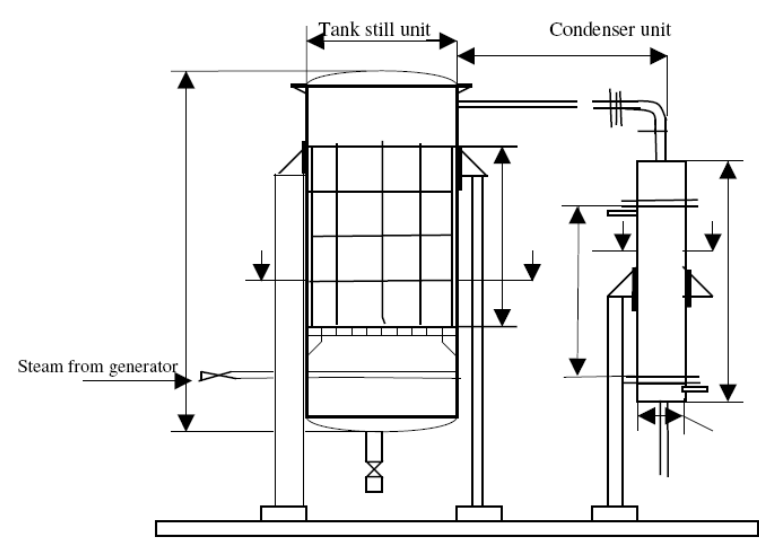

Figure1: Schematic diagram for essential oil production using steam distillation technology

\section{METHODOLOGY}

\section{Study Area}

This study was conducted at National Research Institute for Chemical Technology (NARICT), Basawa, Zaria, Kaduna state. The input data used for the analysis were obtained from relevant literature and series of test-runs carried out on the fabricated essential oil pilot plant located within the Institute's premises. 


\section{Material Collection}

The plant material used was Eucalyptus citriodora leave purchased from Kaduna State Government reserved plantation area at $\$ 70 / \mathrm{kg}$. Kerosene and petrol were bought from nearby filling station at $\$ 100$ and $\$ 70$ per litre respectively.

\section{Analytical Techniques}

The analytical tools employed for the study were relevant equation for calculating annual operating cost, profit after tax, return on investment, return on equity, internal rate of return and pay back period of the project.

\section{Total Plant Cost}

The total cost of any plant (TPC) comprises of both total plant direct cost (TPDC) and total plant indirect cost (TPIC) (John, 2004). Thus;

$\mathrm{TPC}=\mathrm{TPDC}+\mathrm{TPIC}$

In the evaluation of TPDC, method of purchase cost (PC) factor was employed. This method consists of assigning to each element a judiciously chosen factor which when multiplied by the total cost of the equipment gave estimated cost of the plant. Thus;

Total plant direct cost $($ TPDC $)=P C+A \sum_{i=1}^{n} f_{i}$

Where: $\mathrm{PC}=$ purchased cost of the physical equipment.

$A=$ Assigned factor ranged from $5-40 \%$

$\mathrm{f}_{\mathrm{i}}=$ Installation cost, processing cost, electrical facilities and instrumentation cost for each equipment.

The total plant indirect cost (TPIC) was calculated as the total cost of engineering design and construction which were assigned $25 \%$ and $30 \%$ of TPDC respectively.

\section{Annual Operating Cost}

The annual operating cost (AOC) of the plant comprised of raw material cost (eucalyptus leave), total annual production cost (TAPC) and cost of utilities. Thus;

$\mathrm{AOC}=$ Raw material cost $+\mathrm{TAPC}+$ utilities
The TAPC comprised of personnel cost, plant maintenance, supervision, plant overhead, local taxes, insurance, sales expenses, and Research \& Development (Peter et al., 1991)

\section{Profitability Analysis}

The operating profit expressed in naira is the difference between sales revenue and operating cost as given below.

$\mathrm{OP}=\mathrm{SR}-\mathrm{OC}$

Where: $\mathrm{OP}=$ operating profit;

$$
\begin{aligned}
& \mathrm{SR}=\text { sales revenue } \\
& \mathrm{OC}=\text { operating cost }
\end{aligned}
$$

The profit after tax (PAT) was estimated as the difference between operating profit (OP) and sum of depreciation (D) and tax (T).

Thus; $\quad \mathrm{PAT}=\mathrm{OP}-(\mathrm{D}+\mathrm{T})$

$\mathrm{D}=($ Plant cost - salvage value/economic life

\section{Return on Investment}

The return on investment of the project based on the various projections was estimated as the ratio of profit after tax to total investment in the project.

Thus; ROI = PAT/ I

Where: $\mathrm{ROI}=$ Return on investment, \%

PAT $=$ Profit after tax $\mathrm{I}=$ Total investment,

\section{Pay Back Period}

The pay back period is the period expected to recover the investment made in the project and is mathematically expressed as;

$$
\mathrm{PBP}=\mathrm{I} / \mathrm{ACF}
$$

Where: PBP = Pay back period, years

$$
\mathrm{I}=\text { Investment, }
$$

$\mathrm{ACF}=$ Annual cash flow, 
Internal Rate of Return

The internal rate of return of the project was estimated from the following mathematical expression;

$$
-I+\sum_{\mathrm{i}-1}^{\mathrm{n}} \frac{\mathrm{nACF}}{(1+\mathrm{IRR})^{n}}=0
$$

Where: $\mathrm{I}=$ Total investment in the plant,

$\mathrm{I}=$ Economic lifespan of the plant, years

$\mathrm{ACF}=$ Annual cash flow,

$\mathrm{IRR}=$ Internal rate of return, \%

\section{RESULTS AND DISCUSSION \\ Total Plant Cost}

Table 1 presents various costs required by a potential investor to set- up essential oil extraction pilot plant from leafy part of eucalyptus citriodora with a capacity to produce 0.7 litres of essential oil per batch. The estimated cost of the major equipment were \$549,120:00 (Joe-AdeGoke, 2006). These major equipments include steam boiler, distillation tank still and condenser unit. However, other variable costs that made up of total plant direct cost were installation, process piping, instrumentation building and other nondepreciable cost amounting to \$822,576:00. The total plant indirect cost was estimated to be $\$ 452,417: 00$. Therefore, the total investment required by a potential investor to establish essential oil pilot plant with a capacity to produce 0.7 litres per batch (2.8 litres per day) of distilled essential oil was $\$ 1,453,493.00$.This amount include contingency, contractor's fees and size factor.

Table 1: Summary of direct fixed cost estimation

\begin{tabular}{lr}
\hline Item & \multicolumn{1}{c}{ Cost (N) } \\
\hline Total Plant Direct Cost & $822,576.00$ \\
Total Plant Indirect Cost & $452,417.00$ \\
Total Plant Cost & $1,274,993.00$ \\
Contractors' fees & $63,750.00$ \\
Contingency & $63,750.00$ \\
Size Factor & $51,000.00$ \\
Direct Fixed Capital & $1,453,493.00$ \\
\hline
\end{tabular}

\section{Manufacturing Cost}

The basic raw material required in the plant was eucalyptus leave with annual requirement of
$33,600 \mathrm{~kg}$ amounting to $\$ 2,352,000: 00$ at $\$ 70$ per kg. Operating labour was estimated at $\$ 450,000$ :00 per annum for three unskilled workers at N500 per head per day. The estimated annual consumption of both petrol and kerosene were 600 litres and 4,200 litres respectively which translated to $\$ 336,000$ :00 per annum. However, the annual direct production cost of the plant was estimated at $\$ 1,134,315: 00$ and indirect plant cost was estimated at $\$ 204,177.00$ inclusive of sales expenses, factory overhead and Research \& Development. Therefore, the annual operating cost to produce 840 litres of essential oil per annum was estimated at $\$ 4,026,492: 00$.

\section{Profitability Analysis}

Based on the daily output of 2.8 litres of essential oil and annual production of 840 litres (2.8 litres x 300 working days), the expected annual selling price was $\$ 6,300,000: 00$ at $\$ 7,500$ per litre. The expected annual operating profit was $\$ 2,273,508: 00$ and profit after tax of $\$ 1,818,806.40$ at $20 \%$ tax rate. The profit after tax is expected to increase in the subsequent years of operation by increasing capacity utilization of the plant or optimizing the production variables including manpower utilization. However, the economic life span of the plant was assumed to be 10 years with a straight line depreciation of $\$ 130,814$ :00 per annum. The expected return on investment was $125 \%$ with a profit margin of $28.86 \%$ and return of equity of $626 \%$ at assumed value of equity of $20 \%$ of total capital investment. The internal rate of return was positive in excess of $29.64 \%$ at assumed economic life span of the plant of 10 years. The annual cash flow was $\$ 1,949,620$ :40k and a pay back period of 0.75 years. The summary of the profitability analysis is presented in Table 2 .

Table 2: Summary of profitability analysis and return on investment

\begin{tabular}{ll}
\hline Item & \multicolumn{1}{c}{ Cost } \\
\hline Annual Operating Cost & $4,026,492.00$ \\
Annual Selling Price & $6,300.000 .00$ \\
Profit Before Tax & $¥ 2,273,508.00$ \\
Profit After Tax & $1,818,806.40$ \\
Return On Investment & $125 \%$ \\
Net Profit Margin & $28.86 \%$ \\
\hline
\end{tabular}




\begin{tabular}{ll}
\hline Return On Equity & $626 \%$ \\
Annual Cash Flow & $1,949,620.40$ \\
Break Even Point & 0.64 \\
Pay Back Period & 0.75 years \\
Internal Rate of Return & $29.64 \%$ \\
\hline
\end{tabular}

Therefore, from the profitability analysis carried out based on the various assumptions and projections made, It could be seen that with projected earning amounting to $1,818,806: 40$ in the first year of operation, it was quite obvious that the plant is expected to return its initial cost (total investment of 1,453,493:00) in 1 year of operation (pay back period was 0.75 years).

\section{CONCLUSION \& RECOMMENDATIONS}

From the economic performance of the plant presented in this paper it can be conclude that the commercial production of essential oil using steam distillation method is highly profitable and should be attractive to any potential investor. Apart from the fact that the domestic market is grossly under-serviced, the product has great export potential particularly to Europe, Asia and West Africa sub-Saharan region aimed at attracting foreign earning to our country. It is therefore strongly recommended that both state and local Governments in Nigeria should help in establishing such pilot plant in their respective domain, particularly where the raw materials are in abundance. This would help in alleviating poverty by creating job opportunities for teaming unemployed youth.

\section{ACKNOWLEDGEMENTS}

The authors acknowledged the contributions of members of staff of Pilot Plant Division, NARICT, Zaria for their assistance in generating input data used in this analysis during the plant test-run.

\section{REFERENCES}

Ayoade, K. and Daniel, B.A., (2007). Basic concept in process equipment and plant design, Publication of Raw Materials Research and Development Council, Abuja, pp.233-240.

Daw,.Y., El- Barty, G.E. and Muhammad, E.A. (1995). Inhibition of Aspergellius parasitices growth and Aflatoxin production by some essential oils. J. Afr. Crop Sci. 3(4): 511-517.

Encarta encyclopedia (2003). Microsoft Corporation, Encarta library web centre.

Garry, R.P. and Chalchat, J.C. (1995). Essential oils and their development. J. Fruits 50(6): $453-458$.

Galadima, M.S. (2004). Design and fabrication of pilot plant for steam distillation of essential oils. M.sc Thesis.Ahmadu Bello University Zaria - Nigeria. (Unpublished)

Igwe, C.C. (2000). Workshop manual on production and quality assessment of essential oils in Nigeria. Deutchetz Publishers, Lagos- Nigeria. Pp. 6-23.

John, E., (2004). Plant cost and economics. Paper presented in ARCEDEM, Ibadan at workshop organized by RMRDC- Abuja on Design on Process Equipment and Process Plant.

Joe Ade-Goke and Sons Limited (2005). Quotation for fabrication of essential oil pilot plant, submitted to NARICT - Zaria.

Kirk- Othemer (1995). Encyclopedia of chemical technology. 17:.603-671. John Willey and Sons Inc., U.S.A.

Mustapha, Z.O., Fahreltin, G. and Alistiar, C.L. (2003). Subcritical water of essential oils from Thymbra spicata, J. Food Chem. 82: 381-386.

Okonkwo, E.M., Odigwe, J.O., Ugwu. J.O., Muazu, K., Williams, I.S., Nwobi, B.E., Okorie, F.K. and Oriah, V.N. (2006). Design of pilot plant for production of essential oil from eucalyptus leaves. $J$. Scientific Industr. Res. 65: 912-915.

Peter, M.S. and Timmerhaus, K.D. (1991). Plant design and economics for chemical engineers. 4ed. McGraw-Hill, NewYork, U.S.A.

Sridhar, S.R.,Velusamy, R.R., Rejavel, R., Selladumai, M. and Srinivasan, N. (2003). Antifungal activity of some essential oils. J. Agric. Food Chem. 51: 7596-7599.

United Nation Industrial Development Organisation (1983), Practical manual on essential oils industry. UNIDO publication, Vienna, Austrial.Pp.3-4

www. kevala. kevala.co. uk/ aromatherapy/ eucalyptus. Cfm,19/05/2003. 